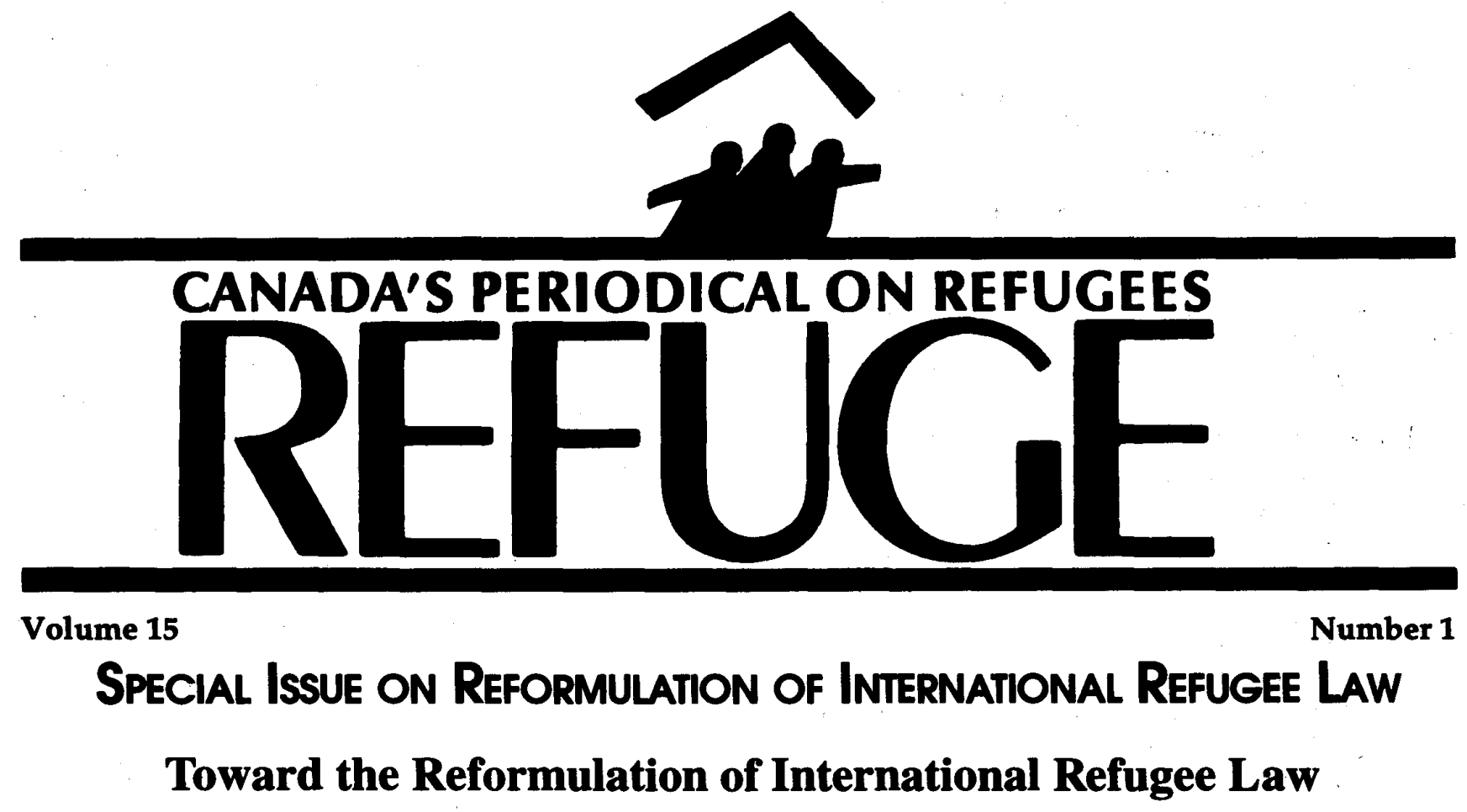

James C. Hathaway

As powerful states have increasingly come to question the consonance of the Convention-based refugee law system with their more general migratory control objectives, a political space has evolved in which fundamental issues of the nature of international refugee protection are tenable for the first time since the immediate post-War era. While it is true that recent reform initiatives have generally been regionalized in scope and often restrictionist in tendency, the Reformulation Project is examining the possibility of re-invigorating a universal protection regime characterized by an enhanced conceptual scope aligned with the norms of international human rights law, yet tailored to take real account of the legitimate interests of receiving countries. Our goal is to promote the reconceptualization of international refugee law based on the three principles of international human rights law, respect for distinct national values, and effective international burden sharing.

The Reformulation Project seeks to promote critical thinking on a "blueprint" for a new refugee protec- tion system which would dispense with the present, arbitrarily assigned, non-collectivized duty of states to provide long-term asylum. Our objec- tive is to investigate the possibility of a more universally accessible and human rights-defined system of refugee law premised not on long-term

\footnotetext{
Contents:

Toward the Reformulation of International Refugee Law

James C. Hathaway . 1

Some Thoughts on the Ethical Dimensions of the Project to

Reformulate International Refugee Law John Haley

Excerpts from Five Studies in Action

I. International Administration Kathleen Newland and Galina Vitkovskaia

II. Fiscal Burden Sharing Amitav Acharya and David B. Dewitt ....... 8

III. Temporary Protection Manuel Angel Castillo and James C. Hathaway 10

IV. Responsibility Sharing Astri Suhrke and Asha Hans.................... 12

V. Repatriation and Development Assistance Robert F. Gorman and Gaim Kibreab.

Toward Reformulation of International Refugee Law: Symposium Report Bill Frelick........................................................ 16

The Next Stage of the Reformulation Project James C. Hathaway ... 23

Research Essay:

Struggling for Legal Status: Mainland Chinese Refugees

Ethnic Mobilization in Canada Tian Guang and Lu Jin. 26
} 


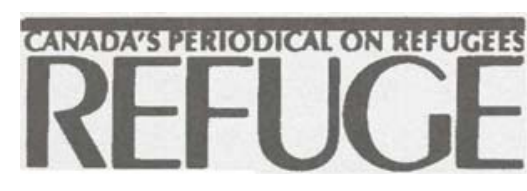

YORK LANES PRESS Centre for Refugee Studies Suite 351, York Lanes York University 4700 Keele Street, North York Ontario, Canada M3J IP3 Phone: (416) 736-5843 Fax: (416) 736-5837 Vol. 15· No.1 January 1996

Editor C. MICHAEL LANPHIER Guest Editors JAMES C. HATHAWAY ALEX NEVE Assistant Editors JEANNE DONALD RACHEL COLLINS MARK SWINDER

Managing Editor ARUL S. ARULIAH

Refuge is dedicated to the encouragement of assistance to refugees by providing a forum for sharing information and opinion on Canadian and international issues pertaining to refugees. Refuge was founded in 1981.

It is published six times a year by York Lanes Press for the Centre for Refugee Studies, York University, Canada. Refuge is a nonprofit, independent periodical supported by private donations and by subscriptions. It is forum for discussion, and the views expressed do not necessarily reflect those of its funders or staff.

All material in Refuge may be reproduced without permission unless copyrighted or otherwise indicated. Credit should be given to the author or source, if named, and Refuge. Submissions on related issues are welcome for publication consideration.

Current subscription rates for one yea (six issues) are: Canada Can.\$50; al other countries U.S. $\$ 60$. (Cheques must be drawn on a Canadian or a U.S. bank.) Current volume single issues 'are available at $\$ 10$ per copy.

Please enclose your purchase order or payment, made payable to York Lanes Press, with your order.

\section{Cdifor.s Xofe}

Beginning with this new volume (15) Refuge is adopting a revised publicatio format. To inaugurate this volume, Professor James Hathaway, Director of the Refugee Law Research Unit of the Centre for Refugee Studies at York University, and colleagues, offer a precis of state-of-the-art position papers on the comprehensive project, "Reformulation of International Refugee Law." This most ambitious project bears wide-ranging implications which, if realised in anything resembling the recommended formulation, will irreversibly alter the current practices on refugee protection, creating a more regularized, universal and equitable system of determining asylum for claimants requiring protection. In offering new rigour to the meaning of burden sharing, this series of articles invites us to rethink the often ad hoc, insufficient and unsatisfactory current set of practices and to envisage, along with the authors, a new regime.

As the reader scans this issue, it is obvious that Professor Hathaway and colleagues are mid-passage-a perfect position to invite comments and constructive criticism. We hope that these articles will stimulate a debate which the magnitude and scope of this project deserves.

From this volume forward, each issue of Refuge will be devoted to a dominant theme, to be presented in a series of articles or sections of a major topic. Six of these thematic issues will appear each year. Additional articles, brief reports and statistical tables will also be included in each issue, on a space-available basis, after the thematic articles.

Refuge continues to welcome contributions on relevant topics, of approximately 4,000 words, including references. Please refer to a recent issue for examples of style.

C. Michael Lanphier, Editor asylum, but rather on temporary protection leading to the restoration of the refugee's right to membership in his or her community of origin. The system would be characterized by an internationally administered process of refugee determination and interim protection in which refugee protection responsibility would be shared out under an interstate system, and in which there would be an equitable sharing of both the financial and human aspects of protection beyond the first asylum stage.

To explore this possibility, we convened a Legal Working Group of twelve recognized experts from around the world in 1993 to help us define the "building blocks" of such a regime. We then commissioned ten of the leading social science experts on refugee protection to work in five North-South teams to elaborate thinking on these building blocks, taking into account the most up-to-date empirical knowledge available. Most recently, we convened a consultation in 1995 of forty experts from academe, governments of the North and South, and the nongovernmental and inter

governmental communities. Their task was to debate the five "Studies in Action" prepared by the North-South social science research teams. Core funding for the project has been provided by the Ford Foundation, now supplemented by a grant from the MacArthur Foundation.

We invited the authors of the Stud ies in Action to consider a number of difficult issues, set out below.

International Administration

Our commitment to a more meaningful international supervisory agencywhich might mean a revamped UNHCR or a new agency-derives from a number of concerns. First, we want protection to be more principled and consistent than is presently possible with individual states exclusively in control. Huge disparities in recognition rates (for example, the United States recognizing Salvadoreans at a two percent rate in the late 1980s while Canada recognized about 
85 percent of Salvadoreans using the same definition) bring the system into disrepute, and dilute its protective capability.

Second, since the proposed system would involve commitments by states to receive recognized refugees under a responsibility sharing formula, and to fund the operations of the system un- status determination procedures and offering related processing and admissions services, we have proposed that UNHCR (or a successor international supervisory agency) take charge of the first asylum and status determination functions. It is assumed that the use of group determination, a common database of country of origin information,

\section{Our goal is to promote the reconceptualization of international refugee law based on the three principles of international human rights law, respect for distinct national values, and effective international burden sharing.}

der a burden sharing formula, there must obviously be real commonality in both the standards and modalities of decision-making. States must be able to place reasonable level of confidence in the accuracy and efficiency of refugee determination carried out by other states if the system is to work.

Third, we believe that there are tremendous cost savings to be realized by moving away from every state running its own determination system. If a generic international administration system could radically reduce the more than U.S. $\$ 10$ billion that developed states spend each year to run their highly legalistic status determination systems (by e.g. using positive group determination processes and a common country information database), then significant monies could be freed up to help fund other parts of the proposed system (e.g. repatriation and development assistance).

\section{Burden Sharing}

As a preliminary matter, we have distinguished two issues: fiscal burden sharing and human responsibility sharing (addressing the allocation of responsibility for receiving refugees). There are three basic costs that would need to be shared under the proposal.

First, a critical piece of our reformulated system would be to induce states to honour the basic duty of non-refoulement (non-return) of asylum-seekers by minimizing the costs of compliance. Given the enormous costs to OECD states of running their individuated etc., would be much less expensive than the present process.

Second, there would be expenses associated with repatriating rejected asylum-seekers and moving recognized refugees to the site of temporary asylum; supervising the compliance by temporary asylum states with relevant human rights norms; and providing "concrete inducements" by way of development assistance to less developed states which receive refugees for the purpose of temporary protection.

Third, there would be collectivized costs associated with the ultimate "return in safety and dignity" of refugees to their homes, including a program of repatriation and development assist-

\section{Temporary Protection}

A first, critical issue is whether temporary protection does in fact make refugee protection a more palatable prospect for states. Is the "numbers issue", which is so routinely raised, truly the concern, or would a system that distinguishes between protecting refugees and permanent admission to a community make the "asylum crisis" less profound? Will temporariness counteract the "pull" dimension of current movements of asylum-seekers? What is the empirical evidence regarding the percentage of refugeeproducing events which could reasonably be expected to be resolved before the expiration of a "temporary protection phase?" Is there "enough value" to ensure that repatriation in safety could become the norm of the regime?

Second, is temporary protection a humane concept that is truly reconcilable with respect for the dignity of refugees? Which human rights of refugees need to be respected as matters of priority? For example, what level of family reunification makes sense? How can one ensure that temporarily protected refugees do not just "disappear into the woodwork," particularly in states with heterogeneous populations and democratic values which

\section{The Reformulation Project seeks to promote critical thinking on a "blueprint" for a new refugee protection system which would dispense with the present, arbitrarily assigned, non-collectivized duty of states to provide long-term asylum.}

ance to bring about meaningful re-integration. Related to this would be the costs of moving those refugees unable to return home safely after expiration of the temporary protection period (probably 5 years) to a country of permanent resettlement.

The critical question, then, is the basis upon which to organize this fiscal burden sharing regime. How could states be induced to participate in such a system? How would obligations be structured and administered? promote internal freedom of movement? Is there an effective means of supervising compliance with refugee rights by the states which afford temporary protection? What kinds of international fiscal support ought to be provided to less developed states which host disproportionate numbers of refugees in order to make a high quality of protection viable? How does one ensure a "flow-through" of that support to refugees, while simultaneously benefitting the local populations, it generates a popular support 
for refugee protection? Is there a way to protect individual refugee rights (including specific concern for the vulnerable among the refugee population), and the collective rights of the refugee population, such that repatriation as a functioning communal entity is really viable?

Third, just how long can temporary protection last? Is the answer the same for all refugees, or do age, sex, family status, and other factors change the answer? How could an internationally administered regime take such matters into account? How could a temporary protection system be made as simple and subject to as few "exceptions" as possible, in order to attract state support, but not at the expense of sensitivity to the real predicaments of refugees?

\section{Responsibility Sharing}

On what basis could the international community be convinced to commit itself to a system of responsibility sharing in refugee protection? In other words, what are the compelling political, moral, or other concerns which should cause us to rethink the current system's reliance on accidents of geography or transportation links as the defining factors in determining who seeks protection where?

Second, while it is illogical, viewed from both a fiscal perspective and in terms of ultimately facilitating repatriation (for both cultural and logistical reasons) to move huge numbers of (mostly rural) refugees in the South to Northern states for temporary protection, how does the Project avoid appearing to legitimate a "new apartheid" for refugees? This raises the very important concept of the "social limits" to the idea (derived from international environmental protection efforts) of "common but differentiated responsibility," which would seem key to a meaningful responsibility sharing system in the refugee context.

A third issue is how to define baseline responsibilities for human responsibility sharing. "Raw numbers" are unlikely to be the right measure of an equitable responsibility sharing sys- tem; instead, account should be taken of the nature of the refugees to be received. Thus, for example, the Scandinavian example of receiving "difficult to settle" refugees, albeit in smaller numbers than other industrialized countries, is seen by some as a possible model for a broader system of responsibility sharing. A related concern is whether pre-existing responsibilities (i.e. refugees already residing in the state) should be factored in to original allocations, or whether the new system should "start from scratch." Further, there is the matter of taking account of the need for residual, permanent resettlement spots for those refugees unable to go home in safety after the expiration of the temporary protection phase. Should countries that are willing to take a larger share of this (more long- community who wish to be protected from the refugee community itself? If some refugees are to be protected outside the region, who should they be?

\section{Repatriation and Development}

\section{Assistance}

A system of repatriation and development assistance should ensure that account is taken of the relative inability of those states which currently receive most of the world's refugees (and which would likely continue to receive a high percentage of refugees under our largely regionalized temporary protection plan) to provide for their needs. Beyond simply "cost recovery," though, the system should aspire to greater balance through the provision of funding which would actually benefit the host community (e.g. support term) responsibility see their temporary protection quotas reduced accordingly?

Fourth, how should the international supervisory agency (UNHCR or its successor) make concrete decisions regarding who is protected and where during the temporary protection phase? In other words, how ought it to be decided which refugees are part of which country's responsibility sharing quota? Because of logistical, fiscal, and cultural concerns-and keeping in mind that the hoped for solution in most cases will be repatriation to the country of origin-a regionalized temporary protection approach seems to make the most sense. Can this objective be fairly achieved without inadvertently creating a "new apartheid"? What weight ought to be attached to individual refugee preferences, and how could this be reconciled to both the need for systemic efficiency and recognition of the value of protecting refugees as a group in order to allow the continuance of their communal traditions pending return? What of victimized minorities within the refugee for common infrastructure, education, etc.). If temporary protection logically dictates a general commitment to regionalized responsibility sharing (for logistical, fiscal, cultural, and viability of repatriation reasons), then shouldn't those states which carry less of the "human responsibility" be seen to owe a duty of compensation to those states which assume a disproportionate share of the universal duty of refugee protection?

The other half of the repatriation and development assistance program would relate to the facilitation of return. Some of the issues raised in this regard include the need to prevent states from "generating refugees" in order to benefit from international development assistance to facilitate their return; the possible need to fine-tune the system to distinguish between the logistics of assistance to "defunct states" (Somalia?) and (reformed) "predator states" (Guatemala?) in terms of the channels for delivering development assistance; how to link the receipt of assistance to a continuing commitment to fair treatment and ef- 